\title{
OIKONYMY OF UKRAINE: A RETROSPECTIVE OF ONOMASTIC RESEARCHES
}

\section{Kotovych V. V.}

\section{INTRODUCTION}

Oikonymy has occupied an important place in the system of human values. It belongs to the cultural heritage of the people and is the very universal historical and social fact that gives the right to interpret it as a peculiar phenomenon of culture. The contemporary Ukrainian multicultural space cannot be analysed or interpreted without this important link in the traditional culture ${ }^{1}$.

Considering the formation and development of Ukrainian oikonymy, researchers focus their attention on the fact that part of oikonyms were formed from appellatives and geographical terms, many were preceded by microtoponyms, some settlements were named after hydronyms or other oikonyms, while others would not have occurred without anthroponyms and their direct or indirect participation in their forming; former cities lost their urban status and became villages or vice versa. However, no matter how the process of establishing the name of the settlement was made, they have the same linguistic and cultural load, because they are formed according to certain linguistic laws and explicate information of the relevant code of culture.

It has already become the standard of understanding that oikonyms as one of toponyms type contain triune information: geographical, historical and linguistic: "A toponym does not exist without the named object, and the objects of the environment are studied by geography. The need for toponyms, their contents, changes is dictated by history, but only through language. A name is a word, a fact of language, not geography or history itself. But the fact is specific, and linguistic knowledge without special toponymic one is not enough to study it"2. This thought, said by Volodymyr Nikonov over fifty years ago, convinces us that in the nineteenth century started, and in the twentieth century on the basis of geography, history, ethnography and linguistics was built a "universe of scientific research" - onomastics. In the twenty first century they spoke of onomocentrism, in which onomastic researches are carried out in close

\footnotetext{
${ }^{1}$ Купчинська 3. О. Стратиграфія архаїчної ойконімії України : монографія. Львів : НТШ, 2016. С. 32.

${ }^{2}$ Никонов В. А. Введение в топонимику. Москва : Наука, 1965. С. 164.
} 
cooperation with ethno-, socio-, eco-, pragma-, psycholinguistics, cognitive science, linguistic philosophy, linguoculturology.

Modern researches of Ukrainian oikonyms began as historical, geographical and ethnographic. The world practice has proved that the systematic work in the field of Slavic and non-Slavic toponymy (oikonymy) began in the same way.

\section{Historical and geographical aspect of the analysis of settlement names}

The establishment of settlements and their naming is a public phenomenon. They, like everything that has come down to us since ancient times - monuments of material and spiritual culture, language, writing, world outlook, customs, etc. - are a product of social relations. Various factors have taken part in their complex historical development, the most important of which are historical, linguistic and geographical. The aspect of studying oikonyms as a historical phenomenon is natural and, as Oleh Kupchynskyi emphasises, perhaps the most important one because it reveals public grounds for the origin of objects and different historical genesis of names ${ }^{3}$. Historicism of oikonyms is expressed not in isolated cases, but forms the "basis of all names", that is, the names of settlements are historical not in narrow sense, reporting an event or name, but always, as "Viktoria or Bukovyna is a story expressed by the means of language" Even artificial oikonyms are "always historical", figuratively and ideologically labelled.

Historicism of many names of settlements "lies on the surface". Especially, when it comes to annalistic oikonyms. In fact, historical onomastics researches formation, development and functioning of onyms in a historical retrospective. Volodymyr Neroznak calls Mykola Barsov the first scientist to begin a systematic study of annalistic toponymy ${ }^{5}$. In "Heohrafichnyi slovnyk Ruskoyi zemli" the author provided information about the geographical objects of Kyiv Rus from the ninth to the fourteenth centuries except for those which were in Turkish or Finnish possession at the time ("belonging exclusively to foreigners of Tatar or Finnish origin") However, researchers have often reproached Mykola Barsov for simply looking for "similar-sounding names" on the maps, which coincided with tribal names and there is little genuine historicism in his works. However, it was Mykola Barsov, "a librarian at the University of Warsaw", who was

\footnotetext{
3 Купчинський О. А. Найдавніші слов'янські топоніми України як джерело історико-географічних досліджень (Географічні назви на -ичі). Київ : Наукова думка, 1981. С. 6.

${ }^{4}$ Никонов В. А. Введение в топонимику. Москва : Наука, 1965. С. 26.

${ }^{5}$ Нерознак В. П. Названия древнерусских городов. Москва : Наука, 1983. С. 7.

${ }^{6}$ Географическій словарь Русской земли : (IX-XIV ст.). Вильна : Тип. А. Сыркина, 1865. С. 8.
} 
able to attract the attention of the scientific community to many problems of toponymy ${ }^{7}$.

Historical researches are closely intertwined with geographical ones. The geographers' interest in the origin of settlement names goes back to ancient times. Later, Yevheniy Pospielov calls the year of 1743, when Vasyliy Tatyshchev (rather a historian than a geographer, but a geographer as well) defined geography as a "description of every region", where "name, language and meaning" are important. This position prompted geographers to interpret a number of toponyms, which was often of a compilation nature, and resulted in the entry of erroneous etymologies into the pages of geographical literature. However, geographers' appeal to toponymy has many positive features. An indication of the spatial localisation of objects that are often not tied to the terrain in historical documents is the most important ${ }^{8}$.

Vadym Zhuchkevych, a creator of the toponymic school of Belarus, speaking about historical and geographical researches, emphasised that natural vegetation, reservoirs, relief, transport routes, agricultural lands are not yet a complete list of information that an experienced geographer can obtain from a skilled reading of toponyms ${ }^{9}$. Geography can never do without space orientation, as history cannot do without time orientation. Toponymy is a peculiar language of geography, an integral part of geographical maps, a generous source of information about the objects ${ }^{10}$.

Demonstration works with a projection on the elaboration of geography with relevance to toponymy or narrower - to oikonymy, are the works by Lev Berg, Petro Semenov-Tian-Shanskyi, Pavlo Tutkivskyi, Stepan Rudnytskyi, Valentyn Sadovskyi, Volodymyr Herynovych, Volodymyr Kubiyovych and other scientists of geography.

In the year of 1839, the Odesa Society of History and Antiquities in the first volume of their Notes published articles by Mykola Nadezhdin "Herodotova Skifia, obyasnionnaya cherez slicheniye s mestnostiami" and "O mestopolozhenii drevnego goroda Peresechina, prinadlezhavshego narodu uglicham", by Mykola Murzakevych "Poyezdka na ostrov Levki ili Fedonisi v1841", by Apollon Skalkovsky "Sravnitelnyi vzgliad na Ochakovskuyu oblast v 1790-1840 godakh", in each of them problems of history, geography and toponymy are more or less intertwined ${ }^{11}$.

\footnotetext{
7 Галас К. Й. Українська топонімія Закарпаття в лінгвістичному аспекті : Учбовий посібник. Ужгород : УжДУ, 1979. С. 8.

${ }^{8}$ Там само.

9 Жучкевич В. А. Топонимика. Краткий географический очерк. Минск : Изд-во БГУ, 1965. С. 8-9.

${ }^{10}$ Стрижак О. С. Назви розповідають. Київ : Знання, 1967. С. 11.

11 Карпенко Ю. О., Фоміна Л. Ф., Зубов М. І., Калінкін В. М. Одеська ономастична школа. Лоус ономастік. № 4. 2012. С. 99.
} 
One of the aspects of historical and geographical researches was the investigation of migration processes, the study of mechanisms for transferring the names of small homeland to the names of newly established settlements. For example, in the early twentieth century (1928) Kost Dubniak placed in "Visnyk pryrodoznavstva" an exploration of the names Askania-Nova and Chapli focusing his attention on the fact that Duke Friedrich Ferdinand von Anhalt-Köthen, who owned a large estate in his homeland called Askania, named his new possessions Askania-Nova in the steppes of Tavriya. The former name of the settlement Chapli (Chapli dacha) gave way to the present one, and regarding the original name the researcher gives an interesting reasoning about the likelihood of its motivation by the appellative chapli 'a steppe plain with many herons', where the heron is a 'dried lake'. Thus, the old name reveals and explains the cycle of natural phenomena, the new one reveals and explains phenomena of historical and social nature ${ }^{12}$. We can only add that the oikonym Chapli (herons) can be regarded as a formation from the family name 'the Chaplias family' with the basic anthroponym Chaplia (heron) ${ }^{13}$. However, such a version will come to science much later, leaving folk etymology a consideration about the "relevance" of the birds inhabited here to the name of the settlement.

Another example of "migration of oikonyms" was given by Mykola Sumtsov: "The large village of Kharkiv county, Vilshanka, got its named not from an alder forest, as one might think, but from Vilshanka near the town of Bohuslav in the present Kyiv region, as all the names of Kharkiv Vilshanka are the same as in Boguslav Vilshanka" ${ }^{14}$. That is, the inhabitants of the settlement gave new lands not only the name of their former village, but also transferred its microtoponyms there.

A real breakthrough in the study of historical geographical names occurred in the twentieth century. Annalistic oikonyms became the subject of the thorough working-out by Volodymyr Neroznak. The scientist was convinced that historical onomastics was based on a comprehensive approach that combines the achievements of a number of historical and linguistic disciplines: ethnic history, historical geography, textology, ethnolinguistics, historical and dialectical lexicology ${ }^{15}$. His work "Nazvaniya drevnerusskikh gorodov", in our opinion, in its historical part tends more to geohistory than to historical geography, taking into consideration that historical geography is included in the subject space of

\footnotetext{
12 Дубняк К. Про назви Асканія-Нова та Чаплі. Вісник природознавства. 1928. № 2. С. 113-114.

13 Демчук М. О. Слов’янські автохтонні особові власні імена в побуті українців XIV - XVIII ст. Київ : Наукова думка, 1988. С. 125.

${ }^{14}$ Сумцов Н. Ф. Малорусская географическая номенклатура. Киевская старина. 1886. № 7. С. 458.

${ }^{15}$ Нерознак В. П. Названия древнерусских городов. Москва : Наука, 1983. С. 14.
} 
geographical sciences and geohistory - of mainly historical ones. For the dictionary of Volodymyr Neroznak, the term geohistorical onomastics would be the most optimal, because it specifies the spatial localisation of the oikonym, collects information of historical chronicles, gives a multivariate linguistic argumentation of the likelihood of any name.

In the same way, however, territorially narrower and methodologically deeper, was compiled the dictionary "Etymolohichnyi slovnyk litopysnykh heohrafichnykh nazv Pivdennoyi Rusi” by Iryna Zheliezniak, Alla Korepanova, Larysa Masenko and Oleksiy Stryzhak. It analyses annalistic geographical names of Southern Rus and the adjacent lands, dating from the ninth-thirteenth centuries and recorded by Old East Slavic chronicles. One of the main tasks of Ukrainian toponymy, according to the authors of the work, is etymological researches, the purpose of their work is to combine broad factual and genetic information about each Old East Slavic annalistic toponym, to establish a connection of material and spiritual culture of the creators of the toponymic system with the names themselves, and they qualify the research not only as a linguistic, but, to a great extent, as a historical and geographical one ${ }^{16}$.

In the late 80 's - early 90 's of the twentieth century all the post-Soviet scholars (at that time Soviet scholars though) spoke of restoring historical names as cultural monuments. Indicative in this regard were the $1^{\text {st }}$ and the $2^{\text {nd }}$ All-Union scientific and practical conferences "Historical names cultural monuments" with the adoption of recommendations for returning historical names to many settlements in the country. It was then that many very valuable theses were made: the return of a historical toponym is not only a desire to erase unworthy names from the map, but instead of them perpetuate new characters with the means of toponymy - it must be a return to the traditional forms of attitude to a language, history, toponymy (A. Solovyova); a historical geographical name is a word that appeared "by itself" as a result of thousands of popular folk uses of indicating any object <...>; anti-historical mass renamings abolish the previous history $<\ldots>$ with their help, toponymy loses history and geography (O. Superanska); the return and preservation of historical names is one of the primary and urgent tasks of modern applied onomastics (V. Shulhach) ${ }^{17}$. Such thoughts sounded not only as a call for reviving historical toponymy, but also for uniting the efforts of historians, geographers and onomastics scientists.

\footnotetext{
${ }^{16}$ Етимологічний словник літописних географічних назв Південної Русі. Київ : Наукова думка, 1985. C. 5-6.

17 Исторические названия - памятники культуры. Вторая Всесоюзная научно-практическая конференция. Москва, 1991. Вып. 3. 215 с.
} 
A historical and geographical interest in toponymy in its time even gave rise to the debate: to whom this area of scientific knowledge belongs: to historians, geographers, or linguists. We think that there is one universal solution to this issue: it is important for the representatives of all these scientific fields to be able to listen, hear and understand each other. And scientific toponymy will benefit from this.

\section{Ethnographic and ethnolinguistic researches of oikonyms of Ukraine}

The beginning of Ukrainian ethnography dates back to Old East Slavic chronicles, documents of the fourteenth-seventeenth centuries, Cossack chronicles of the seventeenth and eighteenth centuries, and in the first half of the nineteenth century there were names of the representatives of three main centres of the scientific and literary movement in Ukraine - Kharkiv, Kyiv and Lviv ones. Selfless work of Hlib Uspenskyi and Izmail Sreznevskyi, Mykhailo Maksymovych and Opanas Markovych, Ivan Vahylevych and Yakiv Holovatskyi contributed to the direction of ethnography on the scientific path and touched not only the heroic past of the Ukrainian people, culture, way of life, customs, folklore, but partly the names of cognised ponds, mastered lands, inhabited dwellings.

The linguistic conclusions of the great Ukrainian scientist, the first rector of Kyiv University Mykhailo Maksymovych, have never been purely theoretical, detached from a lively folk environment. Therefore, Poltava, Pereyaslav, Perekop, according to the researcher's observations, should be designed this way because travelling around cities and villages of the region convinced the Slavic ethnographer (and should also have convinced Shafaryk, who marked them on the Slavic map as Pyvtava, Pereyaslav, Perykyp') that the names Poltava, Pereyaslav, Perekop have always been pronounced and written in Southern Rus ${ }^{18}$.

Ivan Vahylevych is one of the Ukrainian researchers, whose ethnographic observations give reason to speak about the genesis of oikonyms. The scientist considered the names of the settlements Bar, Byblo, Buniv, Kulmatychi, Ruleve, Sopit, Tukhlia to be Celtic by origin, because they were settled and named by the Boykos, and the Celtic tribe of the Boii, according to one version, was the ancestors of the Boykos; the Hutsul oikonyms Pechenizhyn, Pecheniya, Uzyn, Uziv were qualified as Turkic, since according to the author the Hutsuls themselves came from the Turkic tribe of utsi ${ }^{19}$.

\footnotetext{
18 Максимович М. А. О малороссийском произношении местых имен. Собрание сочинений М. А. Максимовича. Київ, 1880. Т. III. С. 329-344.

${ }^{19}$ Бучко Г., Бучко Д. Історична та сучасна українська ономастика : Вибрані праці. Чернівці : Букрек, 2013. C. 416.
} 
"Region names are like a stony document about soil, primitive culture, lifestyle, traditions, customs and settling of our ancestors. Settlement names can clearly illustrate the way which Slavic colonisation took. In cases when there is no historical evidence, the toponyms of the same name convince that the settlers left the area of the same name,"- quoted Vahylevych's sworn brother in the "ruska triytsia" Yakiv Holovatskyi Czech Markian Koliar in the preface to the dictionary "Geograficheskiy slovar zapadnoslavianskikh i yugoslavianskikh zemel I prilezhashchikh stran". The dictionary was published in 1884 in Vilnius. This work was considered to be geographical, but it also posed an ethnological task: to return the cities Lemberg, Budweis, Altsol, Klagenfurt, Neusatz, Fiume, Ragusa and others their specific names like Lviv, Budějovice, Zwoleń, Celovec, Нови Cad / Novi Sad, Rijeka, Dubrovnik, etc., because "Germans, Italians, Hungarians, Turks, having conquered the Slavic lands, destroyed the monuments of national life, distorted geographical terms, or replaced them with brand new ones, borrowed from their own language, and so appeared their topographic nomenclature"20.

Subsequently, Dmytro Yavornytskyi defended the same opinion. Studying cartographic sources, original maps, atlases and plans that were drawn up during the existence of the Zaporizhia Sich and in the first period after its abolition, the scientist analysed an intensive process of distributing the former Zaporizhia lands to new owners. This process was accompanied by naming and renaming the settlements and by a frequent eradication of the former "folk poetry" name ${ }^{21}$. The well-known historian and ethnographer urged to abandon the names brought to the Ukrainian lands from the remotest times by Russians, Bulgarians, Serbs, Greeks, Albanians, Moldovans, immigrants from the Crimea and Greece, and motivated to return everything that was native, autochthonous.

Two books of travel notes - "Narysy Dnipra"22 and "Narysy Dnistra"23 - were left to readers by ethnographer Oleksandr AfanasyevChuzhbynskyi. The first work describes life on the banks of the Dnipro from the rapids and to the mouth: navigation and trade, everyday life of towns and villages, life of residents of Katerynoslav, Kamianka, villages Voloske, Voznesenske, Oleksandrivsk, Tarasivka, Pokrovske, Stanislaviv, Ochakiv. In the second book the author described the life of people from the village of Onut above Khotyn to the Dnister estuary (now the territory of Ukraine and Moldova). He calls the lands from Onut (Anuta) to Khotyn

\footnotetext{
${ }^{20}$ Географический словарь западнославянских и югославянских земель и прилежащих стран. Вильна : Типография А. Г. Сырина, 1884. С. 3-14.

${ }^{21}$ Яворницький Д. Топографический очерк Запорожья. Киевская старина. 1884. № 6. С. 77.

${ }^{22}$ Афанасьєв-Чужбинський О. С. Нариси Дніпра. Львів : Апріорі, 2016. 544 с.

${ }^{23}$ Афанасьєв-Чужбинський О. С. Нариси Дністра. Львів : Апріорі, 2016. 524 с.
} 
Ruska Bukovyna, and considers Bessarabian Ukrainians to be common by origin with Galician. As an argument in favour of the ancient emergence of the Ukrainian population in northern and central Bessarabia serve the names of local settlements, in particular oikonym Khotin'. It is the Slavic name of the town, which in this form (and not Khotyn) was preserved in the speech of the local population ${ }^{24}$.

The collection and systematisation of toponymic material stored in the national memory has become an important task for Isydor Sharanevych. He was convinced that not only the names of towns and villages, but also of mountains, forests, rivers, fields often contain encoded information that helps to find traces of ancient settlements covered by the ground ${ }^{25}$, and the Galician oikonyms like Pomoriany, Polovtsi, Pechenizhyn, Prusy, Prusiv were qualified only as those coming from ethnonyms ${ }^{26}$.

Ivan Franko was one of the first who used the onomastic material to find out the ethnogenesis of the Slavs. In 1911-1912, the scientist published an onomastic investigation "Slidy Rusyniv u Semyhorodi" in the Scientific Supplement to "The Teacher". In it, on the basis of toponymic phenomena, Franko proved the existence of ancient Slavic settlements in Transylvania. Phonetic and morphological features of toponyms testified to the compact residence of Ukrainians there. Ivan Franko started his article with a reference to the work by Mykhailo Hrushevskyi, which proved that since the twelfth century, since the time of the written history of Semyhorod, numerous names have pointed not only to a Slavic but to a Ukrainian trace in this country. Then Ivan Franko found in archival sources collected by Friedrich Miller, a number of toponyms with an explicit indication of their original Ukrainianness: Shybyn (Scybin, Zebin), Khrapun (Chrapundorf), Monastyr (Momostor), Voviv (Wolkow), Rodnia (Rodno), Moshna (Mosna), Zlatna (Zalathna), Olshyna (Olchina), Budz (Budz), Zhytne (Sytne, Zytne), Rosz (Ruzmark, Ruhcmark, Ruzmarge, Reiszmarkt), Wrbow, Bohach (Bogacs, Bagach), Medvizh (Medgyes, Medyes, Medwisch), the Borza River (Borza aqua), the Dumbro River (Dumbro), the Bystrytsia River (Bistritz) and others.

The scientist seldom referred to the etymologisation of toponyms, moreover, not categorically, but only making certain etymological assumptions: Shybyn - "the root shyb - a properly dug pit for mining purposes"; Borza - "cf. borziyi komony (rapid horses) in "Slovo o polku

\footnotetext{
${ }^{24}$ Ільків М. В. "Нариси Дністра” О. Афанасьєва-Чужбинського про старожитності Хотинщини. Вісних Інституту археології Львіського університету. 2013. Вип. 8. С. 66.

25 Борчук С. М. Громадсько-культурна та наукова діяльність Ісидора Івановича Шараневича (1829-1901). Івано-Франківськ: Вид-во Прикарпатського національного університету імені Василя Стефаника, 2009. С. 139.

${ }^{26}$ Худаш М. Л., Демчук М. О. Походження українських карпатських і прикарпатських назв населених пунктів (відантропонімні утворення). Київ : Наукова думка, 1991. С. 44.
} 
Ihorevim" and Galician-Rus borzo meaning quickly"; the Dumbro "obviously, Rus dubrova"; Rodnia - "from ruda (ore) or can be the form of the word ridnyi (native)"; Budz - "the name of something freshly squeezed, obviously raw"; Medvizh - "so called Medvezhyi horod (Bear City)", etc. ${ }^{27}$. The value of Franko's work consists in the fact that at the beginning of the twentieth century he proved the idea that is an axiom today: toponyms (oikonyms) are the ethnoarchive of the earth.

Mykola Sumtsov wrote about the ethnic trace in onyms a little later. The author of the semantic classification of oikonyms, Tatar by origin, provided the names of the settlements Aul, Balakleya, Akhmed, Hadzhivshchyna, Akhtyrka, Lithuanian by origin - Lytovska, Lytvynivka, Lytvynky, Polish - Liashky, Liadske, Liakhovychi. However, what concerned the oikonyms Volka Mazovetska, Liashky Dolishni, Liashky Horishni, Liashky Korolivski, Liashkiv, Liashky Podorozhni, Liakhovtsi, Liatske, Liashky Hostynni, Liashky Zavyazani the researcher listened to the thoughts of his teacher Oleksandr Potebnia, who assumed that a village could arise from a small village where Liashko or Liakhovets lived. That Liashko, Liakhovets, and definitely Liakhovych were no longer Poles, but had such a surname, so the names Liatske and Volia Mazovetska indicate the original ethnic composition.

According to Mykola Sumtsov, Romanian oikonyms or "Ukrainian oikonyms with a reference to Romania" are Bratushany, Stavchany, Petreshty, Tryfoneshty; Voloske, Voloshyno, Volokhivka, Volokhiv Yar, Voloska Balakleika, Voloskyi Kut. However, it is also necessary to distinguish between fact and opinion: does the suffix -an-y in the names of Bratushany, Stavchany really "indicate Romania", are Petreshty, Tryfoneshty the original names and not later ones, modified by Romanians; did Balakleika become Voloska after Volodymyr Shydlovskyi gave it to the Wallachian stolnik Dmytriy Yenakiy, and did Kut become Voloskyi only when it was given to the colonel of Romanian origin Illia Abazi?

Mykytyn Pereviz turned to Nikopol, Yurt to Olhopol, appeared Andrianopol, Mariupol, Orestopol, Fonipol, etc. after eighteen thousand Greeks settled on the shores of the Azov Sea. The memory of the Serbian settlers was preserved in the names of Serbynivka, Serbka, Serbuliv, Serbulivka, Vuicheva, Vukotycheva, Tekeliyeva, of the German colonists in the names of settlements Danzig, Worms, Darmstadt, Neudorf, Blumenfeld, Blumenthal, Rosenthal. Mykola Sumtsov warned: directing the research into the ethnological channel we can make many mistakes. Therefore, it is necessary to consider whether it is logical to derive the

\footnotetext{
${ }^{27}$ Франко І. Сліди Русинів у Семигороді. Назвознавчі пращџі. Вінніпег : Українська Вільна Академія Наук, 1957. Ч. 14. С. 55-80.
} 
names of the settlements Pechenihy and Pechenizhyno from the ethnonym pechenihy, and in the oikonyms Chuhuyev and Kremenchuh see the name of the Polovtsian Khan Chuha ${ }^{28}$.

When linguistic researches in the realm of oikonymy in the midtwentieth century took a course on the priority of structural word-formation investigations over lexico-semantic ones, there were even more reservations.

At the end of the twentieth century linguocentrism gave way to anthropocentrism, and the latter called for ethnolinguistics, the "branch of linguistic science that studies language as a creative product of its representative" 29 .

Ethnolinguistics borders ethnology, cultural studies and psycholinguistics and aims at studying the reflection of ethnic consciousness, mentality, character, material and spiritual culture of the people in the language and speech. The ethno-linguistic direction in linguistics directs the researcher to consider the correlation of language and spiritual culture, language and folk mentality, language and folk creativity, their interrelation and various types of their correspondence ${ }^{30}$. Each layer of natural language, including units with a general denotative orientation, encodes information about a certain fragment of reality that is passed through the prism of the inner world of a native speaker, which absorbs the features of his spiritual culture. Ethno-linguistic researches dealing with dual reflection (a fragment of reality - in the consciousness of a representative of culture, a fragment of consciousness - in the language), respectively, have two interrelated tasks: to determine the specifics of the nationally predetermined perception of the fragment of reality and to show the peculiarities of the language channel of transferring information about such a fragment of reality. Regarding the toponymic material, Olena Berezovych formulates this double task as follows: to identify the originality of toponymy as a linguistic source of information about the spiritual culture of the people ${ }^{31}$. This information is embedded at the level of the ethnogenetic code, since the person originally named the inhabited object in order to single out and fix its defining feature.

It is no coincidence that in one of his articles, Yuriy Karpenko states: "...toponymy (and more broadly, all onomastics) is an ethnogenetic code in everything related to the ethnogenesis and mentality of the people. And

\footnotetext{
${ }^{28}$ Сумцов Н. Ф. Малорусская географическая номенклатура. Киевская старина. 1886. № 7. С. $456-489$.

29 Жайворонок В. Н. Українська етнолінгвістика : Нариси. Київ : Довіра, 2007. С. 8.

${ }^{30}$ Селіванова О. Сучасна лінгвістика : термінологічна енциклопедія. Полтава : Довкілля-К, 2006. 716 с.

31 Березович Е.Л. Топонимия Русского Севера : Этнолингвистические исследования. Екатеринбург : Издательство Уральского университета, 1998. С. 7.
} 
the more ancient time we study, the more important the evidence of this code becomes. We have to adequately read it"32.

Interesting in this sphere is the investigation by Mykhailo Torchynskyi "Ukrainska oikonimiya yak dzherelo etnolinhvistychnoyi informatsiyi", in which the author proves that oikonyms are, first and foremost, elements of culture through which the language reflects the history of settlements, population migration, economy, beliefs, traditions, and it provides a stable linkage of oikonymy with ethnolinguistics. Focusing on reflecting the mentality of the Ukrainian people in proper names of settlements, the scientist speaks about the symbolisation of onyms at the macro level (Kyiv symbolises the whole country; Lviv - the western part, and Kharkiv - the eastern part), and at the micro level (the name of the native settlement represents a small homeland, young age, etc.). The Cherkasy oikonyms Chyhyryn, Subotiv, Kholodnyi Yar became the symbols of the historical past, the freedom of the Ukrainian people. Chornobyl is associated with a tragedy, atomic danger; Yalta - with a rest; Dykanka - with mythology; Sorochyntsi - with a fair; Odesa - with humour and so on. Such symbolic semantics of the word is, of course, merely a reflection of the symbolisation of certain features of the denotation itself, its concept, image, but this phenomenon is quite static, and even when the onym is being transformed as a dynamic category, the symbol will remain in the minds of the speakers for a long time. Mykhailo Torchynskyi's small, but informative investigation gave the scientist to conclude that the national colouring of Ukrainian oikonyms attests to their conformity with the character of our people: positive colouring of many names of settlements, poetic speech, loyal attitude to foreign names, dependence on ideology, nondynamics of the oikonymy system. All this confirms the obvious correlation between language and culture, traditions and customs of our people ${ }^{33}$.

"The whole philosophy of the name is imbued with the spirit of the symbol," says Yuriy Stepanov ${ }^{34}$. That is why it is so important in ethnolinguistics to trace the mechanism of symbolisation of the onym, and the onym not a literary and artistic one, but real, not an anthroponym as the most cultural and not a microtoponym as created mainly by the collective folk experience, but namely the oikonym.

\footnotetext{
${ }^{32}$ Карпенко Ю. О. Топонімія як носій етногенетичного коду. Записки з украӥнського мовознавства. Одеса : Астропринт, 2003. Вип. 12. С. 125.

33 Торчинський М. М. Українська ойконімія як джерело етнолінгвістичної інформації. Наука $i$ сучасність. Київ : НПУ, 2003. Т. 36. С. 131-138.

34 Степанов Ю.С. В трехмерном пространстве языка: Семиотические проблемы лингвистики, философии, искусства. Москва : Наука, 1985. С . 65.
} 
The process of transforming a proper name into a symbol, the creation of connotative onyms or connotonyms, and more broadly, the theoretical foundations of the onomastic connotation, found their place in the works by Yevheniy Otin, and then - by Larysa Bushtian, Halyna Lukash, Viktoria Kanna, Oleksandr Taranenko and others. Oleksandr Taranenko with a regular reference to the dictionary "Slovar konnotativnykh sobstviennykh imion" by Yevhen Otin, the third edition of which contains more than three thousand connotonyms ${ }^{35}$, drew a kind of a peculiar connotative "sociolinguistic map" of Ukrainian toponymy with an emphasis on oikonyms (toponyms) Babyn Yar, Huliaipole, Kyiv, Donetsk, Khutir-Mykhailivskyi, Pereyaslav, Poltava, Lviv, Sevastopol, Odesa, Baturyn, Kruty, Bazar, Berestechko, Zhovti Vody, Konotop, Kobyliaky, Hatsapetivka, Zachepylivka, Zhmerynka, Berdychiv, Chornobyl, Prypyat, Alchevsk, Novobohdanivka ${ }^{36}$. Today this map with a great pain can be supplemented by the oikonyms Ilovaisk, Valnovakha, Debaltseve, Stanytsya Luhanska, Avdiyivka, and with faith and optimism - by the names Bukovel, Kolochava, Opishnia, Petrykivka and others. "The basis for connotonimisation, says Halyna Lukash, is a certain notoriety of a proper name in society; the presence of bright connotems in a proper name that can represent and replace the conceptual denotation of the common name; the stereotypical and repetitive nature of situations that can "awaken" such a connotem; an opportunity to focus on the model of creation of a similar semantic structure developed by language practice" ${ }^{, 37}$. However, if connotation is a way of transforming a prepared proper name into a symbol, then "geographical-landscape, geopolitical, climatic, economic and everyday life conditions of a person form behavioural traits, mentality, spiritual nature of the ethnic group" 38 , which inevitably affects that primary word, which a person nominates a known, created, populated geographical object. Material and spiritual culture, environmental units and significant real and irreal images are embodied in the word-name, and this word becomes an image-idea, almost always nationally labelled. In such a way the proper name captures the spirit of time and space to become a symbol of that spirit. This process may be natural or artificial, long-lasting or instant, more or less successful, but it always arises from the need to name the object, picking up such a verbal mark, which is at that time and in that territory the most appropriate. We are talking about naming when the name of a populated object clearly correlated with an object noticeable

\footnotetext{
35 Отин Е. С. Словарь коннотативных собственных имен. Донецк, 2010. 318 с.

36 Тараненко О. О. На теми сучасного українського ономастикону: тенденції конотативних нашарувань. Мовознавство, 2010. № 1. С. 14-36.

37 Лукаш Г. П. Семіотика конотонімів : знак і символ. Лінгвістика. 2013. № 2 (29). С. 186-192.

38 Жайворонок В. Н. Українська етнолінгвістика : Нариси. Київ : Довіра, 2007. С. 164.
} 
in the territory, or it could give answers who settled here, to whom the settlement belongs, in whose honour it is named, and so on. Therefore, the process of the birth of an oikonym is a reflection of the culture of environment, which becomes its symbol by the will of fate.

Considering ethno-linguistics in the field of related sciences and, in particular, onomastics, Vitaliy Zhaivoronok states: "Oikonyms can tell us much about the history of a people, its ethnogenesis, connections with other peoples. Like common names, not all of them undergo lexical and semantic reconstructions, but often the process of scientific searching, taking into consideration inter-ethnic and inter-linguistic connections, provides food for thought and sometimes unexpected conclusions. ${ }^{39,}$

Ethno-linguistic elaboration of toponymic material today can be of paramount pride for Russian onomastics, declared as separate works with a projection on groups of proper names or on specific onyms and as fundamental onomastic researches performed in the ethnolinguistic way. It will not be an exaggeration to say about the whole ethno-linguistic or ethno-onomastic schools, linguoconceptually, phraseologically, linguoculturally oriented, their creators, representatives and sympathisers became Nina Artiunova, Olena Berezovych, Inna Koroliova, Inna Korolyaye, Valeriy Mokiyenko, Veronika Teliya, Mykyta Tolstoi, Svitlana Tolstova, Maria Rut, Yuriy Stepanov and others.

It is clear that microtoponyms are the most optimal source base for ethnolinguistic researches on onomastics. It is the "folk toponyms", as this class of onyms is often called, that express a deep autochthonous ethnocode, are objectivators of genuine information about the means and methods of national naming of geographical space. But the vast range of modern names of settlements is motivated by microtoponyms, in addition, a correct treating of oikonyms coming from anthroponymous ones, of oikonyms coming from patronymic ones, derivatives of family names, etc., also makes it possible to speak about the outlook, mentality and ethnic identity of the nominee. And as Mykhailo Torchynskyi concludes in the investigation cited above: "the national colouring of Ukrainian oikonyms attests to their conformity with the character of our people"

The post-war ordering of the names of settlements in 1946 was trying to destroy the ethnogenetic code of Ukrainians and all those for whom our lands became native, and settlements became a small homeland. There is more than one investigation about the total renaming of that time in Ukrainian onomastic literature. However, the ethnogenetic code in

\footnotetext{
39 Жайворонок В. Н. Українська етнолінгвістика : Нариси. Київ : Довіра, 2007. С. 32.

40 Торчинський М. М. Українська ойконімія як джерело етнолінгвістичної інформації. Наука $i$ сучасність. Київ : НПУ, 2003. Т. 36. С. 131-138.
} 
oikonyms is a much broader issue than its grief-renamers have seen, erasing the names of settlements Liashky, Prusy, Uhry, Yatviahy, etc. from the geographical map of Ukraine, that is those which, in their opinion, were related to different ethnicities. "If by 1947 in Ukrainian oikonymy more than 30 names of nationalities and nations were shown, such as Basques, Bulgarians, Armenians, Vlachs, Greeks, Kyrgyz people, Chinese, Moldovans, Mordvins, Germans, Poles, Prussians, Serbs, Tatars, Turks, Hungarians, French, Croats, Gypsies, Czechs, Swabians, Swedes, Yotvingians, etc. After 1947, all the names of settlements with these ethnonyms were renamed, including oikonyms with Rus and Ukrainian attributes, which were perceived as identical. The exception is made only for the names Russian" 41 . Moreover, today we are convinced that the etymons of the oikonyms Liashky, Prusy, Uhry, Yatviahy etc. at the time of establishing and naming settlements could be not ethnonyms, but homonymous anthroponyms.

Vitaliy Zhaivoronok, to illustrate the points of intersection between ethno-linguistics and onomastics, traces onymous and ethnonymic parallels in the names of rivers and settlements of Ukraine, Croatia and Serbia: when and how the names of the rivers Khorvatka in Kyiv region, Serben or Serbyn in Ivano-Frankivsk region appeared; what motivated the naming of a number of settlements in the so-called Nova Serbiya in the Right-Bank Ukraine and in Slovyano-Serbiya of modern Luhansk, Donetsk and Poltava regions; why in Zhytomyr region there are settlements like Serby, Serbynivka, Serbo-Slobidka, etc.; why in Croatia appeared Zitomir, Malin, Kiyev, Kiyevci, Kiyevo, Kiyani ${ }^{42}$. There are many questions, and the answers are found at the intersection of related disciplines and when ethnographic researches are transferred to the ethnolinguistic ones.

\section{CONCLUSIONS}

Modern onomastic researches have a solid foundation - historical, geographical and ethnographic ones. Started in the nineteenth century, they led scientists to the conclusions of ethno-linguistic and linguocultural character. The autochthonous name of the settlement speaks of the primordialness of the land inhabited by the Ukrainians, migration processes are accompanied by the transfer of the names of the native settlements, the national colouring of oikonyms is preserved or revived despite social changes and political trends, and artificial ideological names go back to the past, along with their epochs. A person nominates a

\footnotetext{
${ }^{41}$ Бучко Г., Бучко Д. Історична та сучасна українська ономастика : Вибрані праці. Чернівці : Букрек, 2013. С. 228.

42 Жайворонок В. Н. Українська етнолінгвістика. Київ : Довіра, 2007. С. 32-33.
} 
populated object taking into consideration naming traditions of his time and previous epochs. Spiritual and material culture of the name-giver, ways of interaction between man and nature, peculiarities of perception and comprehension of the surrounding reality, migration and colonisation processes, awareness of his responsibility for naming a settled object - that is an incomplete list of ways of studying onyms through the prism of anthropocentrism.

The anthropocentric paradigm designed at the end of the twentieth century differs from the previous paradigms (comparatively historical and systematically structural) about transfer of research interests from the object of cognition to the subject - the person who speaks, and in the perspective of onomastic researches - to the person who names. Such a name traces the ethnic, national, social, cultural nature of the nominator, his way of thinking. History, geography, ethnography, local history are good companions of onomastics, which can demonstrate a reliable source base, a precise localisation of settlements, national specificity and national colouring of the name.

Today, in the centre of the scientific linguistic paradigm is a person who recognises and masters the surrounding space and actively nominates it. Oikonymic researches are a linguistic- (lexico-semantic, structurally word-forming, etymological), historical- (synchronous-diachronic), geographic- (stratigraphically spatial), cultural (material-spiritual) study of the name of each settlement or oikonymy as a system. In such investigations, history is sure to answer the question - when?, geography where?, linguistics (including onomastics) - how? Therefore, only the joint efforts of historians, geographers, ethnographers, and using the scientific conclusions of these sciences can lead onomastics researchers to a correct establishment of the genesis of oikonyms.

\section{SUMMARY}

The article provides an overview of the historical-geographical and ethnographic researches of the oikonymicon of Ukraine. The basic principles of conducting such work by the researchers of the nineteenth the beginning of the twentieth centuries have been outlined. Oikonymy of any region is formed in time and in space, possesses general features and specific peculiarities, encodes lingual and extralingual information. The author has proved the importance of studying oikonyms as a historical phenomenon, has emphasised the necessity of carrying out toponymous investigations by geographers, has clarified the specificity of considering the genesis of settlement names by ethnographers, has traced how ethno- 
linguistic researches of Ukrainian oikonymicon sprout on the basis of these investigations.

It has been proved that the anthropocentric linguistic paradigm involves the transfer of research interests from the object of cognition to the subject - the person who names the object through the prism of the native language.

\section{REFERENCES}

1. Афанасьєв-Чужбинський О. С. Нариси Дніпра. Львів : Апріорі, 2016. 544 c.

2. Афанасьєв-Чужбинський О. С. Нариси Дністра. Львів : Апріорі, 2016. $524 \mathrm{c}$.

3. Березович Е. Топонимия Русского Севера: Этнолингвистические исследования. Екатеринбург: Издательство Уральского университета, $1998.338 \mathrm{c}$.

4. Борчук С. М. Громадсько-культурна та наукова діяльність Ісидора Івановича Шараневича (1829-1901). Івано-Франківськ : Вид-во Прикарпатського національного університету імені Василя Стефаника, 2009. 211 с.

5. Бучко Г., Бучко Д. Історична та сучасна українська ономастика : Вибрані праці. Чернівці : Букрек, 2013. 456 с.

6. Галас К. Й. Українська топонімія Закарпаття в лінгвістичному аспекті : Учбовий посібник. Ужгород : УжДУ, 1979. 120 с.

7. Географический словарь западнославянских и югославянских земель и прилежащих стран. Вильна : Типография А. Г. Сырина, $1884.445 \mathrm{c}$.

8. Географическій словарь Русской земли : (IX - XIV ст.). Вильна : Тип. А. Сыркина, 1865. 220 с.

9. Демчук М. О. Слов'янські автохтонні особові власні імена в побуті українців XIV - XVIII ст. Київ : Наукова думка, 1988. 172 с.

10. Дубняк К. Про назви Асканія-Нова та Чаплі. Вісник природознавства. 1928. № 2. С. 113-114.

11. Жайворонок В. Н. Українська етнолінгвістика. Київ: Довіра, 2007. 262 c.

12. Жучкевич В. А. Топонимика. Краткий географический очерк. Минск : Изд-во БГУ, 1965. 322 с.

13. Етимологічний словник літописних географічних назв Південної Русі. Київ : Наукова думка, 1985. 254 с.

14. Ільків М. В. "Нариси Дністра” О. Афанасьєва-Чужбинського про старожитності Хотинщини. Вісних Інституту археологіi Львіського університету. 2013. Вип. 8. С. 65-74. 
15. Исторические названия - памятники культуры. Вторая Всесоюзная научно-практическая конференция. Москва, 1991. Вып. 3. $215 \mathrm{c}$.

16. Карпенко Ю. О. Топонімія як носій етногенетичного коду. Записки з украӥнського мовознавства. Одеса : Астропринт, 2003. Вип. 12. С. $120-125$

17. Карпенко Ю. О., Фоміна Л. Ф., З Зубов М. І., Калінкін В. М. Одеська ономастична школа. Лоус ономастік. 2012. № 4. С. 98-112.

18. Купчинська 3. О. Стратиграфія архаїчної ойконімії України : монографія. Львів: НТШ, 2016. 1278 с.

19. Купчинський О. А. Найдавніші слов'янські топоніми України як джерело історико-географічних досліджень (Географічні назви на ичі). Київ : Наукова думка, 1981. 252 с.

20. Максимович М. А. О малороссийском произношении местых имен. Собрание сочинений М. А. Максимовича. Київ, 1880. Т. III. C. 329-344.

21. Нерознак В. П. Названия древнерусских городов. Москва : Наука, 1983. 208 с.

22. Никонов В. А. Введение в топонимику. Москва : Наука, 1965. $179 \mathrm{c}$.

23. Отин Е. С. Словарь коннотативных собственных имен. Донецк, 2010. 318 с.

24. Поспелов Е. М. Топонимика в региональных географических исследованиях. Москва : Московский ФГО, 1984. 110 с.

25. Селіванова О. Сучасна лінгвістика : термінологічна енциклопедія. Полтава : Довкілля-К, 2006. 716 с.

26. Степанов Ю.С. В трехмерном пространстве языка: Семиотические проблемы лингвистики, философии, искусства. Москва : Наука, 1985. 335 с.

27. Стрижак О. С. Назви розповідають. Київ : Знання, 1967. 40 с.

28. Сумцов Н. Ф. Малорусская географическая номенклатура. Киевская старина. 1886. № 7. С. 456-489.

29. Тараненко О.О. На теми сучасного українського ономастикону : тенденції конотативних нашарувань. Мовознавство, 2010. № 1. С. 14-36.

30. Торчинський M. M. Українська ойконімія як джерело етнолінгвістичної інформації. Наука і сучасність. Київ : НПУ, 2003. T. 36. C. 131-138.

31. Франко І. Сліди Русинів у Семигороді. Назвознавчі пращі. Вінніпег: Українська Вільна Академія Наук, 1957. Ч. 14. С. 55-80. 
32. Худаш М. Л., Демчук М. О. Походження українських карпатських i прикарпатських назв населених пунктів (відантропонімні утворення). Київ : Наукова думка, 1991. 268 с.

33. Яворницький Д. Топографический очерк Запорожья. Киевская старина. 1884. № 6. С. 77.

\section{Information about the author: Kotovych V. V.,}

Candidate of Philological Sciences, Associate Professor at the Department of Philological Disciplines and Methods of Their Teaching in Primary School, Ivan Franko Drohobych State Pedagogical University 24, Ivan Franko str., Drohobych, 82100, Ukraine 